\title{
ROBÔ PARA INSPEÇÃO DE ÁREAS CLASSIFICADAS E DE DIFÍCIL ACESSO COM TRANSMISSÃO DE IMAGENS SEM FIO
}

\author{
Jonathan Pereira \\ IFRN - Campus Mossoró. E-mail: jonathan@cefetrn.br \\ Alexsandro Galdino \\ IFRN - Campus Mossoró. E-mail: anny_m14@hotmail.com \\ Lucas Almeida \\ IFRN - Campus Mossoró. E-mail: tygerman_22@hotmail.com
}

\section{RESUMO}

Mediante a necessidade de monitoramento de áreas de difícil acesso ao homem ou áreas que levem risco a sua integridade física, esta pesquisa tem por objetivo construir um robô que faça a captura de imagens por um sistema totalmente sem fio e controlado por computador. Para isso fez-se necessário o projeto e implementação mecânica e eletrônica de um protótipo composto de servomotores, um microcontrolador, um módulo de rádio para a comunicação entre robô e computador e um sistema de captação e transmissão de imagem sem fio. Para a implementação do software que proporciona a execução de comandos remotos, desenvolveu-se uma aplicação utilizando o ambiente C++ Builder ${ }^{\circledR}$. Em toda a implementação fez-se uso de conceitos visto nas disciplinas de programação de computadores, eletrônica analógica e digital, microcontroladores, sistema de transmissão de dados e mecânica.

PALAVRAS-CHAVE: Monitoramento, Robô, microcontrolador. 


\section{ROBÔ PARA INSPEÇÃO DE ÁREAS CLASSIFICADAS E DE DIFÍCIL ACESSO COM TRANSMISSÃO DE IMAGENS SEM FIO}

\section{INTRODUÇÃO}

Na última década os sistemas robóticos experimentaram grande evolução técnica graças principalmente aos avanços ocorridos nas áreas da computação, microeletrônica e mecatrônica. Dentre esses sistemas destacam-se os veículos operados remotamente (VOR), que pertencem à classe dos robôs de inspeção, e que são usados em larga escala nas áreas industrial, militar e espacial. Em geral eles são empregados em ambientes de difícil acesso ou que contenham materiais perigosos.

Os VORs ou ROVs (Remotely Operated Vehicles) ganharam visibilidade e popularidade mundial graças ao seu emprego em missões arrojadas, tais como no caso do robô Spirit, um ROV terrestre enviado pela NASA ao planeta Marte; ou no caso do robô Scorpio, um ROV submarino da real marinha inglesa que atuou com sucesso no resgate dos tripulantes do submarino russo AS-28. A necessidade de explorar áreas de alto risco para o ser humano ou de espaço físico muito reduzido, leva a pesquisa e o desenvolvimento de novos equipamentos.

O protótipo construído possui acionamento diferencial realizado por dois servomotores que estão conectados a uma placa eletrônica formada essencialmente por um microcontrolador um drive e um módulo receptor de rádio, este último tem por função receber e decodificar as informações que são enviadas pelo módulo transmissor. Na placa de transmissão estão mais um microcontrolador e o módulo transmissor de rádio. A placa transmissora recebe os comandos pela porta de comunicação serial do computador e os envia para o robô pelo rádio.

O projeto visa envolver alunos dos cursos técnicos do IFRN, buscando fortalecer o núcleo de pesquisa em eletrônica e sistemas microcontrolados com o objetivo final de desenvolver equipamentos que possam se tornar produtos aplicáveis no âmbito industrial e residencial.

\section{METODOLOGIA}

A pesquisa foi iniciada com o projeto de toda a eletrônica a ser utilizada para possibilitar o controle do robô pelo computador. Como o enlace de comunicação é sem fio, fez-se uso de módulos de rádio para transmissão e recepção dos comandos de acionamento. O passo seguinte foi o desenvolvimento do software aplicativo responsável pelo envio dos comandos pela porta de comunicação serial até a placa que realiza outro processamento e envio das informações pelo rádio. Constatado o funcionamento do protótipo, promovemos os testes de campo para verificação de interferências eletromagnéticas.

O Protótipo é composto de dois servo-motores e uma placa eletrônica constituída de um microcontrolador, um drive de acionamento e um módulo receptor de rádio. Na fase de projeto, todo o circuito para o controle e acionamento do robô foi implementado em matriz de contatos. Como pode ser observado na figura 1. 


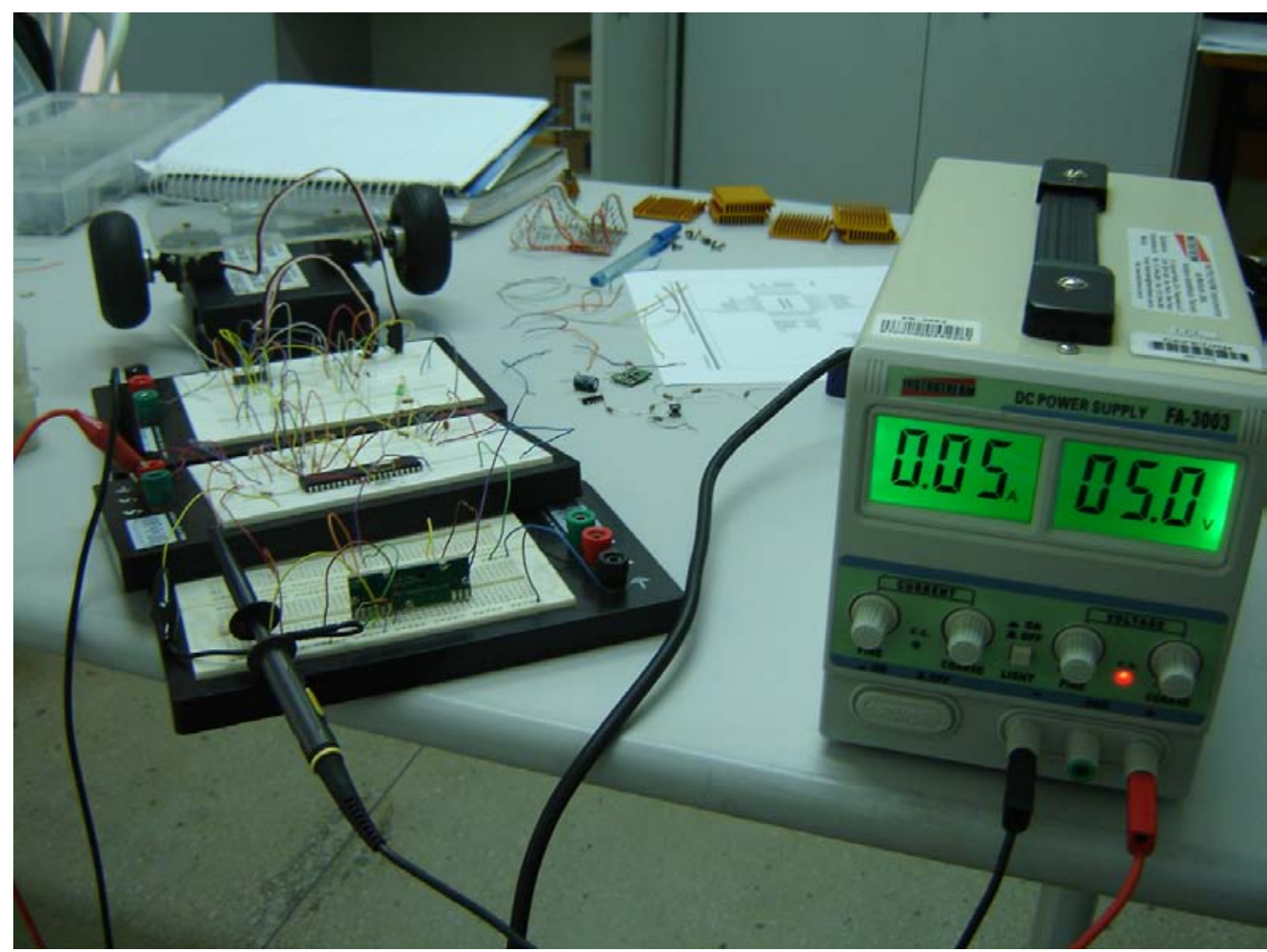

Figura 1 - Fase de projeto dos circuitos de acionamento do robô

O drive utilizado no acionamento dos motores foi o L293, escolhido pelo seu tamanho e capacidade de conduzir o nível de corrente exigido pelo conjunto. A figura 2 mostra a configuração do drive utilizada para acionamento de dois motores com possibilidade de inversão no sentido de rotação.

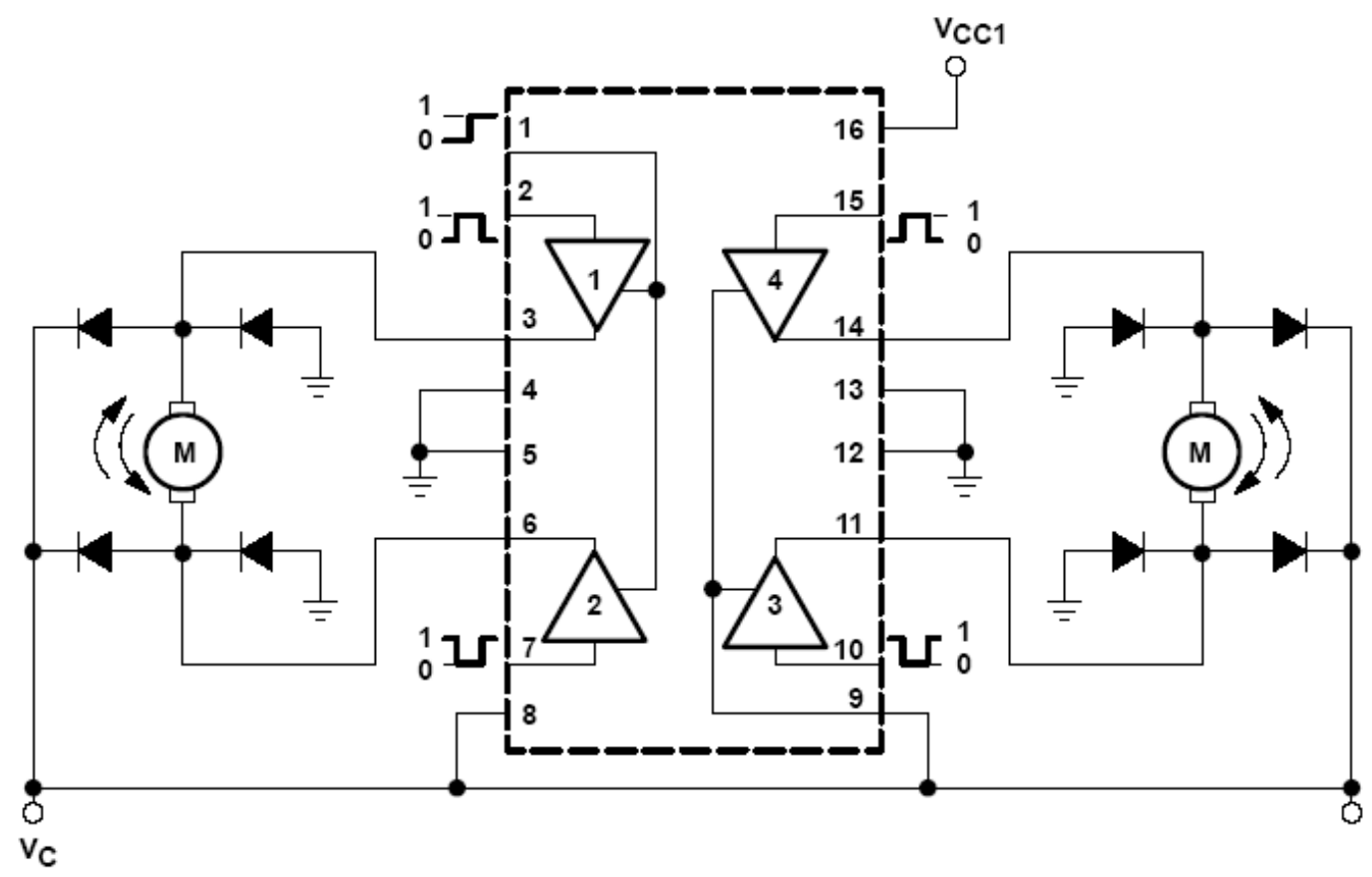

Figura 2 - Configuração da ponte H L293 para acionamento de dois motores 
A fase seguinte foi a responsável pelos testes de comunicação entre transmissor e robô. A transmissão era realizada pelo placa formada pelo microcontrolador PIC 16F877A que recebia pela USART caracteres no padrão ASCII emitidos pelo computador através da porta de comunicação serial. Esses dados eram então enviados ao módulo de rádio que os transmitia até o receptor localizado no robô. A figura 3 ilustra a placa responsável pela interface entre o micro e o módulo transmissor.

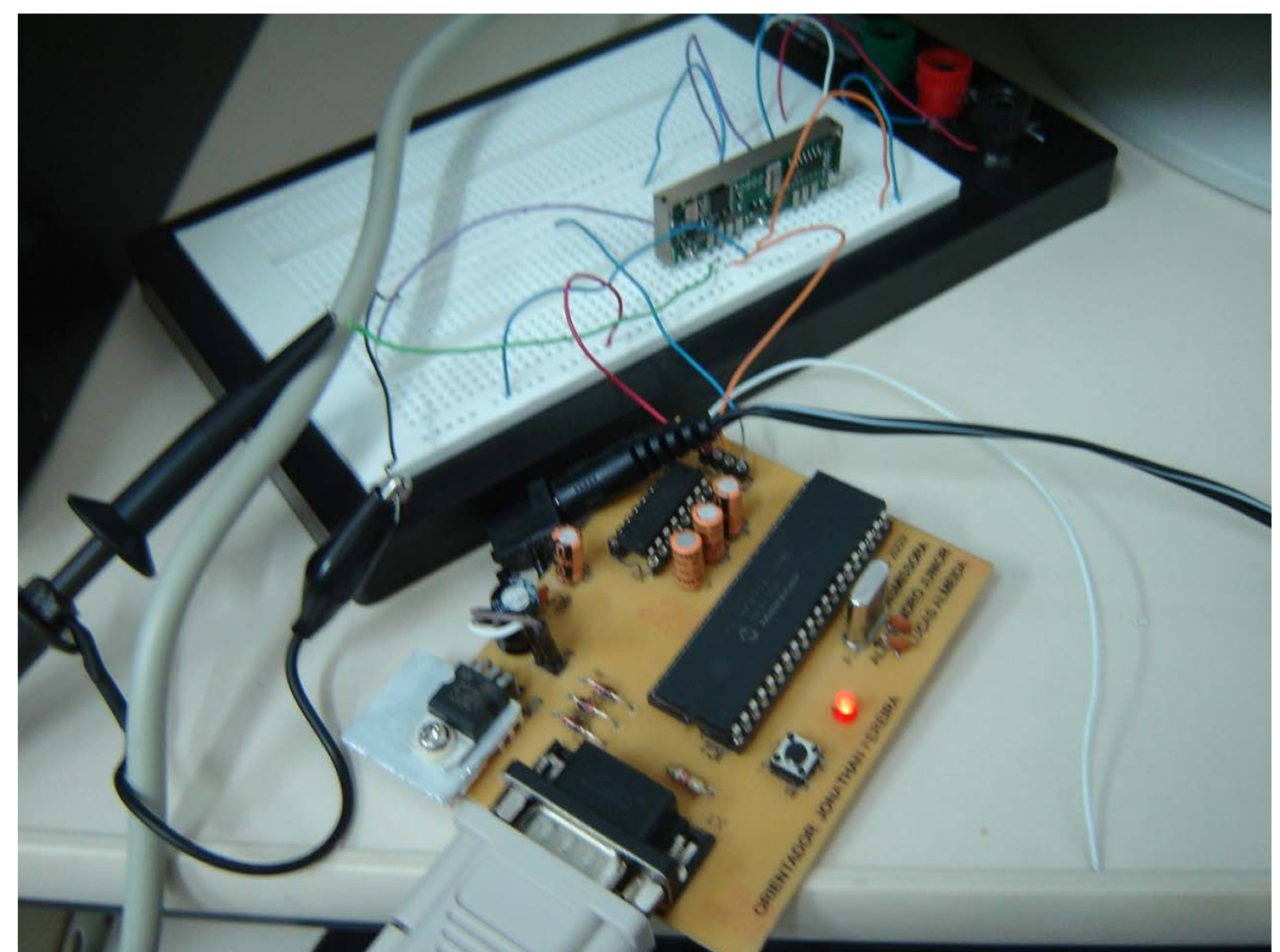

Figura 3 - Em primeiro plano a placa de interface com o PC e em segundo plano o módulo de comunicação de rádio

Para verificação do correto envio dos dados entre PC e placa transmissora e entre esta e o robô, fez-se uso de um osciloscópio para regulação das velocidades de comunicação e verificação de interferências como pode ser observado na figura 4. 


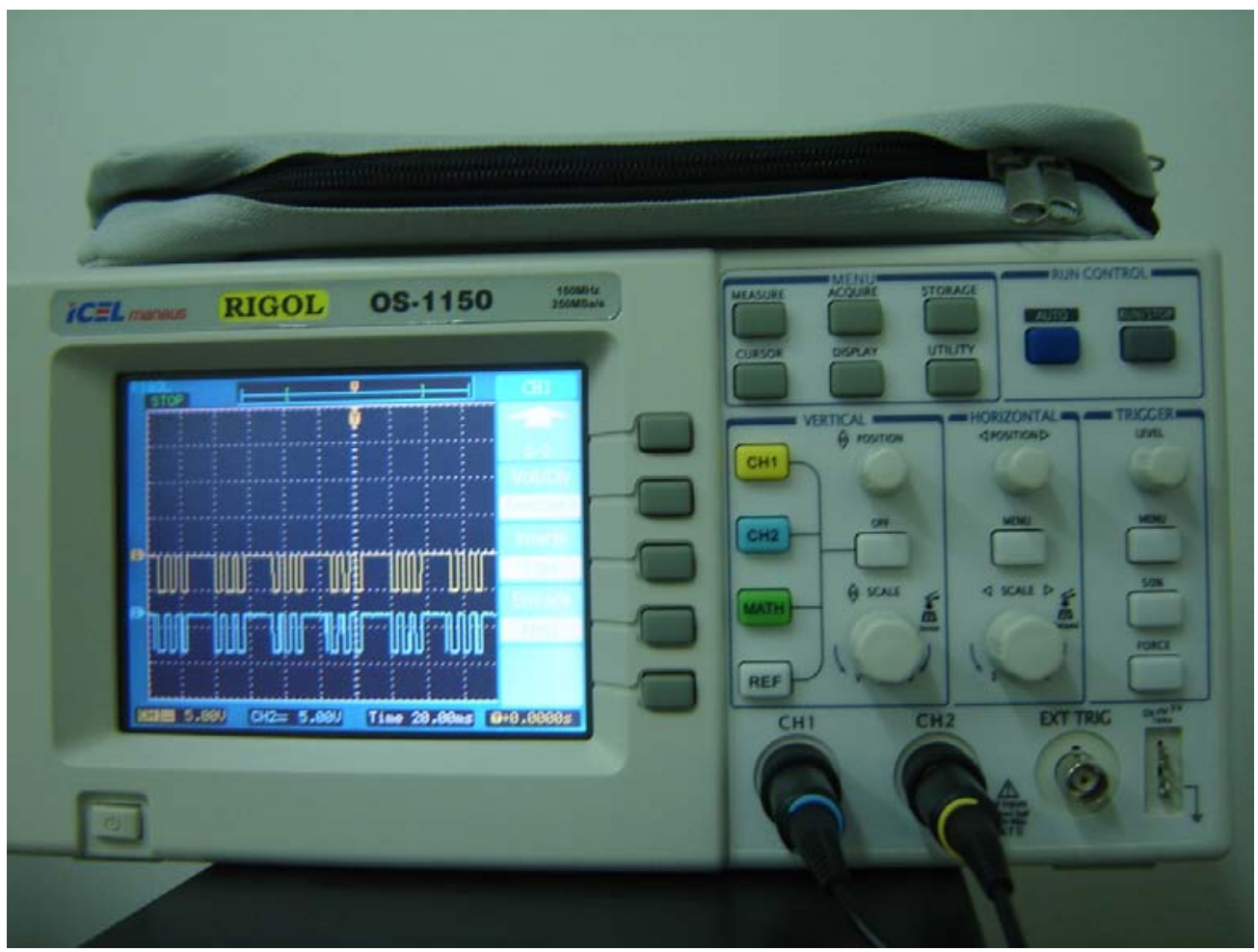

Figura 4 - Osciloscópio mostrando os sinais do transmissor e do receptor

A figura 5 mostra o robô com o sistema de captação de vídeo formado pela câmera e o módulo transmissor.

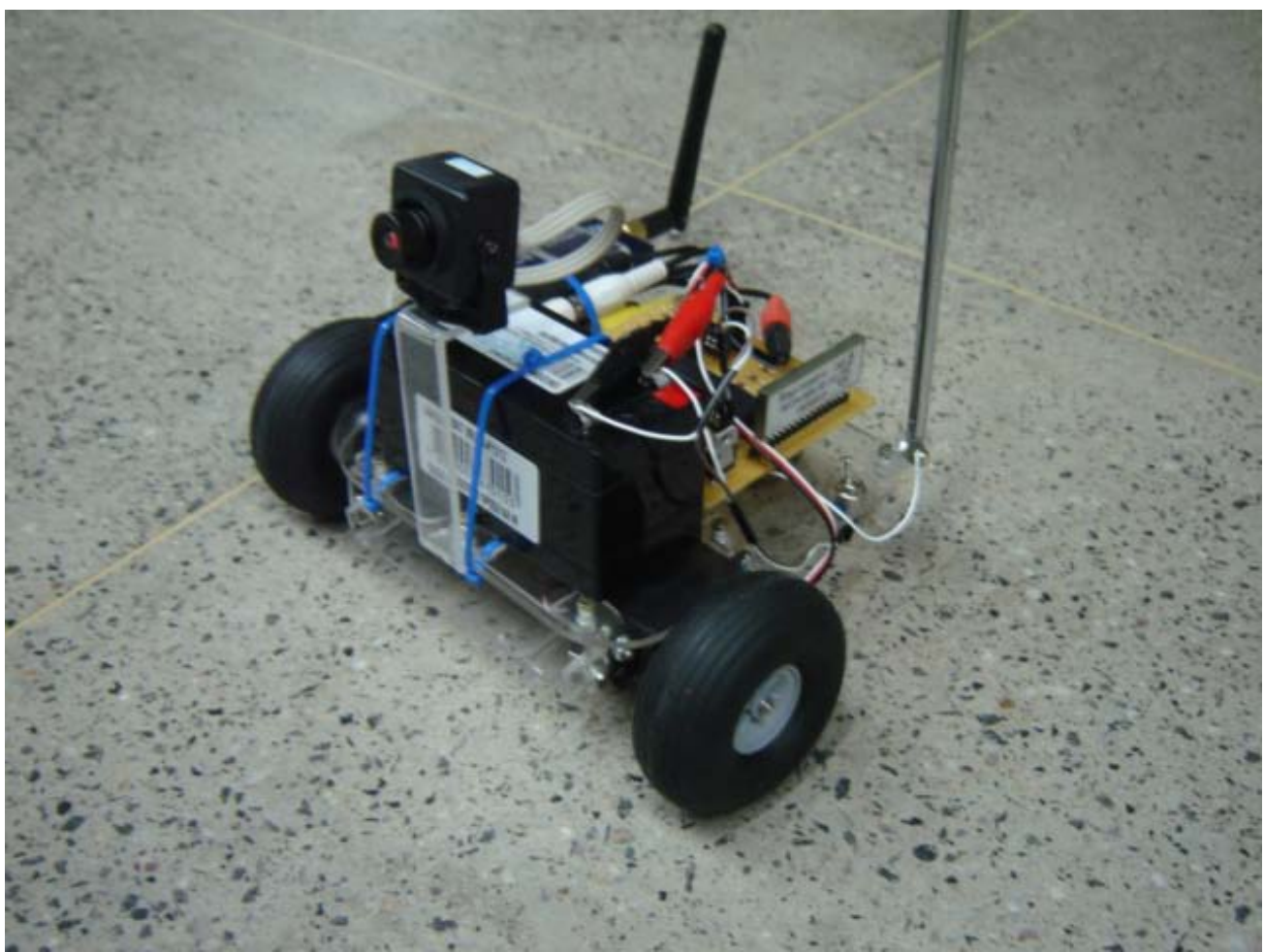

Figura 5 - Foto do robô 


\section{RESULTADOS}

Dentre os resultados obtidos pela pesquisa e desenvolvimento do protótipo, podemos ressaltar o ganho de conhecimento teórico e prático por parte dos alunos envolvidos nas áreas de eletrônica e informática.

O projeto desenvolvido também recebeu grande visibilidade em exposições de eventos como a EXPOTEC do IFRN - Campus Mossoró, e será apresentado no Fórum Mundial de Educação Profissional e Tecnológica, o qual será realizado em Brasília, DF.

\section{CONCLUSÕES}

De uma maneira geral, pode-se considerar que as atividades desenvolvidas durante o projeto e a pesquisa realizada quanto a sua aplicabilidade foram bem sucedidas. Com o custo relativamente baixo contraposto com seus benefícios. O projeto mostrou-se ser totalmente viável dentro das condições e necessidades do mercado, e que pode ser introduzido nas mais diversas áreas da indústria, tendo em vista o uso de um sistema de transmissão que possibilita o envio de vídeo a uma grande de distância.

\section{REFERÊNCIAS BIBLIOGRÁFICAS}

PEREIRA, Fábio. Microcontroladores PIC - Técnicas Avançadas. Ed. Érica. 6ed

PEREIRA, Fábio. Microcontroladores PIC - Programação em C. Ed. Érica. 7ed 